Journal of Language \& Translation 11-2

September 2010, 207-226

\title{
Translating African Proper Names in Literary Texts
}

\author{
Babatunde Samuel Moruwawon \\ University of Ado Ekiti
}

\begin{abstract}
This paper analyses proper names in Yoruba culture and the translation of African names in three African literary texts, emphasizing the non-arbitrary nature of African names using a historical and textual approach. Ethical considerations for translating these texts into another language call for translation strategies that are likely to carry across the subversion of these cross-cultural texts. The paper concludes that the study of African proper names allows a foreign reader to have an insight into the African world-view and the socio-cultural values of African names.
\end{abstract}

Keywords: yoruba culture, African names, translation, proper names

\section{Introduction}

Proper names are regarded as set designations of singular objects: given names, patronymics, last names, place-names, titles of books and works of art. Proper names may refer to setting, social status and nationality of characters, and demand attention when translating them from one culture into another culture. They play an essential 
role in African literary fictions. Works on onomastics by Akinnaso (1980), Onuigbo (1996), Fernandes (2006), and Agyekun (2006) Ozidi (2008), have again emphasized the relevance of proper names in literary works and African culture. The varying structure of personal names in Africa can be appreciated through the grammar of the language in question. This paper analyses proper names in Yoruba culture and the translation of proper names in three specific African literary texts Ferdinand Oyono' Une Vie de Boy (1960) translated into English by John Reed as The Houseboy, Chinua Achebe's Things Fall Apart (1958) translated into French by Michel Ligny as Le Monde S'éffondre and Ahmadou Kourouma's Les Soleils des Indépendances (1970) translated into English as The Suns of Independence. Ethical considerations for translating these texts into another language call for translation strategies that are likely to carry across the subversion of these cross-cultural texts.

\section{Cultural Significance of Yoruba Proper Names}

Proper names among the Yoruba have socio-cultural and ethnopragmatic meanings that transcend ordinary identity. Among the Yoruba, proper names can be viewed from two perspectives: what names mean to the Yoruba people and what names reveal about the culture of the people. Agyekun (2006) uses the term indexicality to refer to socio-cultural interpretation of names. Agyekun cited in Ozidi's (2008) typology of Akan personal names is similar in many ways to the Yoruba, Malinké in Ivory Coast, and Ewondo in Cameroon:

Day names, family names, circumstantial names, theophorous names, flora and fauna, weird and reincarnate names, achievement names, stool (i.e royal names, religion, occupational), insinuating and proverbial names, bodily 
structure and kingship...." (Agyekun 2006: 206)

In Yoruba culture, a child has three names which will guide the child for life. The first is the "Oruko", (personal names), which is either an "Amutorunwa" (brought from heaven) name or an "Abiso" name. Second, is the "Oriki" (praise name) which expresses what the child is or what is hoped he or she will become. The choice of an "oruko" name depends on many factors such as the time of the day, a special day or a special circumstance relating to the child, parents, extended family or the whole community that attends the child's birth. The "amutorunwa" name applies to children born under like circumstances. The most important of these is the "ibeji", (twin birth). The "ibeji" is the "orisa" of the "twin gods". "Ibejis" are considered dangerous to their parents and thus, feared. They were thought to have extra-human powers (Barret 1977). The name of the first born twins is called "Taiwo", meaning "to have the first taste of the world". "Kehinde" that is, he who lags behind, is the second born. "Idowu" is regarded as stubborn and heady and if he does not arrive after a mother's twins, there is a superstition that the mother may go mad; the wild and stubborn "Idowu", flying into her head will render her insane. "Alaba" is the name given to the child born after "Idowu". "Oni", that is, today, is name given to a child that is next to "Idowu". Among the Isin people, the names are taken up to the eight born called "Ijoni". Other "amutorunwa" names are: "Ige", a child born feet first, "Abiose", a child that is born on a holy day; "Dada", a child that is born with curly hair; "Abiodun", a child that is born during annual festival and "Johojo", a child whose mother died at its birth. Among the "oruko" name, we have "abiku", that is, born to die children. These are believed to belong to a group of demons that reside in the woods around "Iroko" trees. Before they come into the world, they have already chosen the time when they will die. Special names are given to these children with the hope that they will not die on their pre-arranged dates. These names are: 
"Maloma", that is, do not go again, "Ikumapayi", that is, do not die, "Mayugbo", which means, do not go again. In pre-Christian period, Yoruba names are attached to deities. The nick name of these deities is "orisa" and is connected to the natural forces that command and create life. These "orisa" are:

Orunmila- the oracle god

Sango- $\quad$ god of thunder and lightning, the fourth ruler of Oyo empire,whose wife is "Oya", the goddess of the River Niger

Obatala god of creation

Osun- goddess of fertility and water

Ogun- god of war, the hunt, and all pursuits in which iron or steel is used

Ifa- $\quad$ god of divination, wisdom and incarnation at the philosophical, religious, scientific and metaphysical level.

Egugun- symbolizes all dead ancestors

Yemoja goddess of waters having a father called "Oduduwa" who is a friend of "Sango", the god of thunder and lightning.

With the advent of Christianity, names emphasizing Christian virtues and ideas become prominent. These names are: Ifeoluwa, (love), Igbagbo, (Faith), Ooreofe, (Grace), Aanuoluwapo, (Mercy), Ebunoluwapo,(Gift); Oluwaseun, (Victor) and Ilerioluwa, (Promise) among others. Yoruba belief in reincarnation. Any diseased family can be reincarnated for preservation and continuity of the deceased person in the family. A new born baby in the family is given such name as "Babatunde" that is, father has returned, for female deceased member of a family and "Iyabode" for female. To ensure that every child knows his origin, he or she is instructed in the family history. 


\subsection{Culture and Translation of Proper Names in Specific African Literary Texts}

One of the most difficult problems in translating African names is found in the differences between cultures. Different cultures have different focuses. When cultures are similar, there is relatively less difficulty in translating. This is because both languages will probably have terms that are more or less equivalent for the various aspects of the culture. When the cultures are very different, it is often difficult to find equivalent lexical items Larson (1984: 956). A translator who uses a cultural approach in the translation of African names recognizes that African language contains linguistic features which are derived from its culture, and that conventions of text production and reception vary from culture to culture. The recognition of this makes it appropriate to affirm that the translation of African names is a process which occurs between cultures.

Nord (1997: 34) uses the term "cultureme" to refer to culture specific items. He defines "cultureme" as a cultural phenomenon that is present in one culture but absent in the other culture. Gambier (2004: 159) refers to such concepts as:

Culture-specific references connoting different aspects of every day life such as education, politics, history, art, institutions, legal systems, units of measurement, place names, foods, and drinks, sports and national pastimes, as experienced in different countries and nations of the world Gambier. (2004: 159)

Considering literature as the product of a dominant ideology, it is obvious that sign systems cannot be assumed to be understood by everyone, for language is dynamic and apt to change.

Hervey and Higgins (1986) proposed two strategies in the translation of proper names in literary translation. They affirmed 
that either the name can be taken over unchanged from the source text into the target, or it can be adopted to conform to the phonic or graphic conventions of the target language Hervey and Higgins (1986: 29). They refer to the former as exotism which "is tantamount to literal translation, and involves no cultural transposition, and the latter as transliteration." Further to this, they suggest another translation method namely: cultural transplantation, a translation procedure in which the source language names are replaced by indigenous target names that are not their literal equivalents but have similar cultural connotations (ibid: 29). Newmark (1988: 214) affirm that "normally, people's first and sure names are transferred, thus, preserving national and assuming that there names have no connotations in the text. The procedure of transference cannot be said to be effective strategy in cases where connotations and implied meanings are significantly relevant. There are some names which bear connotations and require a specific translation procedure to translate them. As a solution, Newmark's (1988a: 215) proposes that the translator should first "translate the word that underlines the source language proper name into the target language and then naturalize the translated word back into a new source language proper name. The strategy is useful in the translation of proper names:

\section{Analysis Using Specific African Texts}

This section will examine the translation of proper names in three African literary texts. These texts are Ahmadou Kourouma's Les Soleils des Indépendances (1970) translated by Adrian Adams as The Suns of Independence; Ferdinard Oyono's Une Vie de Boy translated into English by John Reed as The Houseboy. Chinua Achebe's Things Fall Apart (1958) translated into French by Michel Ligny as Le monde s'éffondre. (1966). 


\subsection{Ahmadou Kourouma's Les Soleils des Indépendances as: The Suns of Independence}

\subsubsection{The Title of the Text}

The title of our text reads "Les Soleils des Indépendances" translated as: The Suns of Independence. In the English translation, Adrian Adams paid great attention to its translation in the Target Text, thus making the translation unique and adequate. The language strategy of Ahmadou Kourouma explains the africanisation of the French language which is the very characteristic of Ahmadou Kourouma's writing. It is a subversive method used by Ahmadou Kourouma. This is because the French language in the hand of Ahmadou Kourouma is no longer the exclusive creation of the metropolis, but rather a hybrid of French and African languages. This is a deconstruction of the French language. The polysemy of "Les Soleils" translated as: "The Suns" is purely polysemous in its creation by Ahmadou Kourouma:

(1) ... Le soleil! Le soleil! Le soleil des indépendances maléfiques remplissait tout un côté du ciel, grillait, assoiffait l'univers pour justifier les malsains orages des fins d'après-midi.(9)

... The sun!, the sun! the cursed sun of independence filled half the sky, scorching the universe so as to justify the unhealthy late afternoon storms.(5)

(2) Les soleils des indépendances s'étaient annoncés comme un orage lointain et dès les premiers vents Fama s'était débarrassé de tout: négoces, amitiés, femmes pour user les nuits, les jours l'argent et la colère à injurier la France, le père, la mère de la France.(22)

Like a distant storm, the suns of independence had 
given warning of their coming and at the first gusts of wind which Fama had shed everything: trade, friends, women to use up his night s and days, his money and his anger in railing against France.(13)

(3) Cette période d'agitation a été appelée les soleils de la politique. Comme une nuée de sauterelles les indépendances tombèrent sur l'Afrique à la suite des soleils de la politique.(22)

That period of agitation has been called the suns of politics; after the suns of politics, independence fell upon Africa like a swarm of grasshoppers.(14)

From (1) above, Ahmadou Kourouma uses the name "soleil", in the singular form, as a pun. There is no doubt that the sun is being referred to here. From examples (2) and (3), the plural form of the the name "soleils" is used in a connotative sense. When one critically analyses this name "soleils", which is rendered as "suns" by the translator, we are tempted to ask whether these "suns" refer to the "unimagined "suns" in the heavens that have brought untold hardship to the Africans. However, it is obvious from the original text that "les soleils" in (3) above connote the independence period when the politicians exploit the African masses:

(4) Vraiment les soleils des indépendances sont impropres aux grandes choses; ils n'ont pas seulement dévirilisé mais aussi démystifié l'Afrique. (149)

Truly the suns of independence are unsuited to great things; they have not only unmanned, but also unmagicked Africa.(100)

(5) Fama, couché et repu, s'était vautré sur la natte, prêt à dégainer pour sabrer, faucher et vilipender la bâtardise des politiciens et des soleils des indépendances.... Le 
parti unique de la République interdisait aux villageois d'entendre ce que pourraient conter les arrivants de la capitale sur la politique.(97)

Fama, reclining full-fed on his mat, was prepared to unsheath his tongue and lash out with a cut-and-thrust denunciation of the bastard politicians and suns of independence..... The Republic's single party forbade villagers to listen to anything people arriving from the capital city might say about politics.(65)

(6) Ces soleils sur les têtes, ces politiciens, tous ces voleurs, et menteurs, tous ces déhontés, ne sont-ils pas le désert bâtard où doit mourir le fleuve Doumbouya? (99)

These suns overhead, these politicians, all these shameless people, these liars and thieves, are they not the bastard deserts where the great Dumbuya river must disappear? (66)

(7) Ajoutons qu'après le départ des voyageurs le soleil monta rapidement: Mais, et cela ne s'était jamais vu en plein harmattan dans le Horodougou. (153)

Let us add that after the travellers had left, the sun swiftly rose. But, and this was unheard of in Horodugu... (102)

In Ahmadou Kourouma's sense of the name "soleils" in (1), (2), and (3) the "suns" refer to the politicians represent "suns". They symbolize the leaders of the people, they are those who quest and agitate for independence. If Adrian Adams chooses to render the English translation of the Source Text literally, she may end up mistranslating the sense of Ahmadou Kourouma. In (7), "le soleil" means the central body of the solar system, that is "the sun". The sun, of course, is the central body of the solar system, a star around 
which the earth and other planets revolve and from which they receive light and heat. In French Le Petit Robert (1978) defines "soleil" as Astre qui donne lumière et chaleur à la terre, et rythme la vie sur sa surface. Our analysis gives an insight into how the human mind understands sense in translation. In other words, as long as sense can be made out of words, group of words, phrases, or sentences, re-expression in the target language becomes easy and fluent. However, in monolingual communication, it is obviously much more difficult to study the way in which comprehension builds up, since most of it occurs unconsciously.

It can be assumed that our analysis can be extrapolated to Adrian Adams' comprehension of the source text in general. This comprehension is not a linear process, that is, from verbal elements to knowledge, but a constant intermingling of language and extralinguistic knowledge of Adrian Adams. It is knowledge that has been stored in her cognitive memory that she then uses for comprehension. She achieves this first, by assimilating this new knowledge and in doing so, accommodates it, thus giving rise to a new adapted pattern in the target text. Adrian Adams' approach is patterned after what Tymoczko (1999) calls Piaget's cognitive science:

In general, cognitive science suggests that we tend to assimilate new and unfamiliar information to patterns that are already recognized and that have already become familiar, and there is evidence from studies of the brain that there is a biological basis for this tendency. (48)

Our analysis reveals the impact of the interpretative approach and the problem Adrian Adams faces in order to translate the equivalent title of Ahmadou Kourouma's Les soleils des indépendances. Her English translation of this title thrives on the recognition of the nucleus elements against the search for virtual identities. 


\subsubsection{Translation of Cultural Names}

Cultural names used by Ahmadou Kourouma in Les Soleils des Indépendances are the results of language contact. These names are "Horodougu" translated as "Horodugu", "buccale", that is Antelope, "dolo" translated as "millet beer", "nago" translated as "nago" and "Toubabs These cultural names evolve from complex collection of experiences and conditions of Ahmadou Kourouma's daily life. These names leave only two ways in which they can be translated to the target reader: transcription on the one hand, and substitution on the other hand. Since the target text is intended to give detailed information on Malinké culture and history, all categories of cultural names translated in the target text are very important and related to cohesion and coherence in terms of the textuality of the source text narrative. Furthermore, Adrian Adams' translation strategy is guided by investigating the standardized use of these words before reconstructing them into the target language standardized equivalents. The same situation is applicable in the translation of distinguished personalities and geographical names such as "Fama" translated as: 'Fama", and "Horodougou" translated respectively as: "Horodugu". In cases where there are no standardized use of these names in the target language, the translator is guided by the importance of these names in terms of coherence, the nature of these names in the source language with their peculiar characteristics, the combinatory possibilities governing word formation in the target language and finally with the knowledge that the target reader of the translation would consider every single item in the original work extremely important. The cultural names "cha-cha" and "foutou", "fonio" translated as "toh", "futo", are French but their sense reflect purely malinké idiolect. For instance, the translation of "cha-cha" as "chachas" is a name given to malinké cylinder-like instrument used for entertaining people by the griots during ceremonies. "Foutou" is adequate if fluently translated as "fufu" for the English reader of the 
Target Text, being the name given to prepared yam flour or, plantain flour in the Anglophone context. In Yoruba speaking southwestern Nigeria it is known as "elubo fufu". The cultural name "les nago" is translated as "nago." Awareness of history by Adrian Adams is an essential requirement in the translation of a work coming from a foreign culture, that is, malinké culture. The manlinké name for "nago" refers to the foreign race in the Ivory Coast, specifically the Yorubas. The name Yoruba itself, was fixed on the people by the northern neighbors and later popularized by colonial publications.' Before then, the "nago" to which some Yoruba in the present Benin Republic and others in the new world still use to refer to themselves, was used to refer to most of the people called Yoruba today. A common origin and language, as well as common political and religious cultures made the Yorubas a nation long before any contact with Europeans and the advent of colonialism.

Upon the death of Oduduwa, there was the dispersal of his children from Ife to found other kingdoms. These original founders of the Yoruba nation included Olowu of Owu (son of Oduduwa's daughter), Alaketu of Ketu (son of a princess), Oba of Benin, Orangun of Ila, Onisabe of Sabe, Olupopo of Popo, and Oranyan of Oyo. Each of them made a mark in the subsequent urbanization and consolidation of Yoruba confederacy of kingdoms, with each kingdom tracing its origin to Ile-Ife. In view of the derogatory use of this name in the text, the translator decides to substitute the name in the target language equivalence. Should she have translated "Yoruba" or "foreigners" in the Target Text, she would not have translated Ahmadou Kourouma's intention in using the specific name. Thus, thorough knowledge of a foreign language, its vocabulary and grammar is not enough to make Adrian Adams a competent translator of Les Soleils des Indépendances. She is not only familiar with her own culture but also with the Malinké culture before attempting to build a bridge between them in her English translation. 
"Des Toubabs" is translated as the "Europeans". The contextual use of the name facilitates its proper interpretation by the translator in Yoruba context this name is called "Oyingbo" or "Oyinbo alawofunfun". Our analysis of the above names and their translations reveals the following facts: First, it shows that there is a distinction between the meanings built in and the meaning that must be understood and expressed in the English translation of Les Soleils des Indépendances' proper names. In other words, the translator is caught between the need to capture the local colour of the Source Text names and the need to be understood by an audience outside the original cultural linguistic situation. Second, our analysis also reveals the distinction between the meaning that is built in the text and the meaning that must be captured and re-expressed in the Target Language and culture by Adrian Adams.

This is in effect saying that even though both the source language (French) and the target language (English) predispose Ahmadou Kourouma and Adrian Adams to the different aspects of their environment, Adrian Adams does not merely translate these cultural names with similar meanings but first recognizes them as words to be interpreted with malinké sensitivity while applying her creative ability to translate them. For this reason, Adrian Adams' English translation of Ahmadou Kourouma's Les Soleils des Indépendances initiates the target language reader into the malinké world-view and naming philosophy, thus making her a translator who possesses great virtue and contextualized intuition, that is, the ability to find the nearest common sense interpretation of the "not found" equivalent elements within its context.

\section{Textual Analysis: Une Vie de Boy rendered as The Houseboy}

\subsection{Oyono's Title: Une Vie de Boy as Houseboy}

The goal of any translation is to ensure that the Source Text and 
220 Translating African Proper Names in Literary Texts

the Target Text communicate the same message, while taking into account the constraints placed on the translator. Traditionally, translation as a human activity takes into account a number of constraints which involve context, grammar rules of both Source and Target Languages and the Source Text expressions as well as conventions. John Reed translates Oyono's "Une Vie de Boy" as "Houseboy". Looking at Oyono's title from a literal perspective, one would have thought that the translator should have rendered this title as: "The Life of a House Boy". The idea of "life" is totally lost in the English translation of the Source Text's title. The houseboy syndrome was very much pronounced among the British in colonial times. Oyono himself, instead of choosing his title as: "Une Vie de Serviteur" deliberately uses "boy" in his original composition of the Text. Thus, Oyono's colonial experience reflects in the composition of the original title of the Source Text. John Reed's translation is a product of the British attitude to the blacks who they saw as inferior. This old colonial mentality also recflects in the use of the term : "boy's quarters" depicting the black residence of the black servants of the whites. "Boyi" in Yoruba cultural name is inferior to "Okunrin", that is, an "adult man".

John Reed's initial task involves an analysis of certain lexical groups that constitute an expression to be understood before their eventual translation in the Target Text. This recognition is essential so as to redirect the translation in the Target Language towards a non-literal sense of this expression. If the translator had failed in his initial task, the resultant rendition would have represented a literal translation as: "The Life of a Houseboy". Thus, the effectiveness of John Reed's strategy in the translation of "Une Vie de Boy" as "The Houseboy" preserves the semantic content of the Source Text in the Target Text. His translation strategy is a useful tool for communicating a great deal of multi-word units which cannot be deduced from their individual components in just a few words. Good examples of these multi-word names abound in Yoruba: 
"Ranti omo eniti iwo nse" which denotes "Remember your origin" and "Idunnun subu layomi", which means "Joy". The shortened form of this name is "Ranti". Though the lexical constituency of the Source Text's title differs from the Target Text, the semantic content of this title in the target text is semantically the same in the two languages: French and English.

\subsection{John Reed's Translation Toundi's name}

In the translation of Une Vie de Boy, the word Joseph being the baptismal name of Toundi is chosen by Oyono to give maximum effect in the Source Text. It does not only create a precise image but also evokes association that suggests unexpressed details in the source text:

(8) Je m'appelle Toundi Ondua. Je suis le fils de Toundi et de Zama. Depuis que le Père m'a baptisé, il m'a donné le nom de Joseph. Je suis Maka par ma mère et Ndjem par mon père. (16)

My name is Toundi Ondua. I am the son of Toundi and of Zama. When the Father baptized me he gave me the name of Joseph. I am Maka by my mother and Ndjem by my father. (11)

The name "Joseph" as the baptismal name of Toundi can be linked to the Joseph of the Old Testament of the Christian Bible who is falsely accused of desiring the wife of Potiphar, the Egyptian. Not only is Toundi given a Christian name on joining the Church and the colonial world, it is the same church which sets him on the road that leads to his eventual destruction despite his innocence. Toundi's name as translated by John Reed gives us a picture of Christianity and its transforming effect on African cultural identity. The name "Whites" is the name given to the British colonial masters in Africa. 
This is a assumed name of the British in their former colonies. This assumed name is different from nickname. Nicknames are often given to the bearer by others, and are at times derogatory, and often are attempts at portraying some perceived physical features, characteristics or behavioural traits of the bearer. Assumed names are taken by the bearer himself and are reflections of the bearer's outlook, aspirations, hope and desires. John Reed's translation of this imagery is compact and well packaged for the assimilation and consumption of the Target Reader of Une Vie de Boy.

\section{Chinua Achebe's Things Fall Apart Translated as Le Monde S'effondre.}

Chinua Achebe's Things Fall Apart translated by Michel Ligny is successful in the translation of charactonyms. Charactonyms are names that perform a characterizing function Alexander(2006). Charactonyms are given names. They perform a descriptive function. One of the signs of a charactonym is its common stem. Let us consider some examples from the text:

(9) Okonkwo was well known throughout the nine villages and even beyond. His frame rested on solid personal achievements. As a young man of eighteen, he had brought honour to his village by throwing Amalinze the Cat. (3)

Okonkwo était bien connu à travers les neuf villages et même au-delà. Sa réputation reposait sur de solides réussites personnelles. Jeune homme de dix-huit ans, il avait apporté honneur et gloire à son village et terrassant Amalinze le Chat. (9)

(10) In the end Okonkwo threw the Cat. (3) 
A la fin, Okonkwo terrassa le Chat. (9)

(11) Kotma of the ash buttocks

$\mathrm{He}$ is fit to be a slave

The White man has no sense

He is fit to be a slave. (123)

Kotma aux fesses de cendres,

Il est bon pour faire un esclave

L'homme blanc n'a pas de bon sens

Il est bon pour faire un esclave. (211)

The relevance of the significant element must be suggested by means of motivator in the translation of charactonym. From the above, the motivator is part of the text expressed by the means of synonym, the Cat" rendered as "le Chat", giving the name its characterizing function. Contextually, Amalinze was the great wrestler who for seven years was unbeaten from Umuofia to Mbaino. He is given the name "the Cat" because his back would not touch the earth during wrestling. It must be noted that Okonkwo's culture is achievement oriented. Achebe (1958) makes the following remark about Okonkwo's society:

(12) Age was respected among his people but achievement was revered. As the elders said, if a child washed his hands he could eat with kings. Okonkwo had clearly washed his hands and so he ate with kings and elders. (6)

L'âge était respecté parmi les gens de son people mais la réussit était réverée comme disaient les anciens. Si un enfant se lavait les mais, il pouvait manger avec les rois. Okonkwo s'était indubitablement lave les mais et c'est pourquoi il mangeait avec les rois et les anciens. (ibid. 1) 
The translation of "kotma" as "kotma" in the French translation is a charactonym. The name "kotma" is not of Ibo origin; it is a name that is used to qualify the corruption of the "white court messengers." These court messengers were greatly hated in Umofia because they were foreigners and because of their arrogance and high-handedness. A charactonym may have different shades of meaning in the contexts within the text. The translation of charactonym has no absolutely permanent meaning in the text. It may express a continuum. But the motivator allows the translator to find the main characteristics dominating others. The meaning of the expressive name "kotma", though derogatory, is reinforced by the motivator "court messengers" who are the white colonialists.

As part of the strategy used to translate charactonyms, the translator should note that dictionaries are not perfect authorities because they cannot keep up with all the changes that take place in the text, but provide standards that alert us to alternative variants and ambiguity. From the above, the name reflects the characteristics expressed by the significant element from the source text. It also characterizes the court messengers by the same trait. Thus, the translator copes with the transformation of the name successfully in terms of colouring and characteristics. The equivalents which reflect the characteristics of their bearers can be realistically described as relevant equivalent. In the translation of the above names into French, the translator takes into account stylistic colouring. The stylistic colouring of the significant element in the target text is close to the source text labelling. Charactonyms being the artistic creation of the source author is closely connected with the whole figurative system of a literary work. Michel Ligny's transfer of charactonyms of the target text is close to the source text; the translator performs a poetic function that is also of high value. 


\section{Conclusion}

In choosing to study proper names in Yoruba and three African literary texts, we do so in the knowledge that similar features of these names exist in all African communities and our findings, thus, reflect the phenomenon of proper names in African society. The study of proper names gives us an insight into the socio-cultural basis for African proper names. From the study, cross-cultural studies of proper names yield important clues about the relationship of such names with socio-cultural, behavioural patterns in different societies. It also reveals how intertwined African names are with the culture. Translating the semantic, and semiotic values of African names with ample evidences of spatial, temporal, personal, religious, historical and gender deixis can be stimulating to a foreign reader whose worldview of the African culture and literary genre in question would be greatly enriched Ozidi (2008).

\section{References}

Achebe, C. 1958. Things Fall Apart, Heinemann Ltd., 1-158.

Michel, L. 1966. Le monde s'éffondre. Présence Africaine., 1-254

Agyekums, K. 2006. The Sociolinguistic of Akan Personal Names in Nordic Journal of African Studies 15(2): 206-235.

Akinnaso, N. 1980 "The Sociolinguistic Basis of Yoruba Personal Names". Anthropological Linguistics: 22, 275-304.

Akintoye, O. 2010. Yoruba Omo Oduduwa. Papers on Yoruba People, Language and Culture. African Language Program, University of Georgia. Available at URL

$<$ http//:www.edu/aflang/yoruba/oduduwa.htm. $>$

Alexander, K. 2008. Translation of charactonyms from English into Russian. Available at URL

$<\mathrm{http} / /$ :www.translationdirectory.com/article1119.htm.> 
226 Translating African Proper Names in Literary Texts

Fernandes, L. 2006. Translation of Names in Children's Fantasy Literature: Bringing the Young Reader into Play in New Voices in Translation Studies 2, 44-57.

Gambier, Y. 2007. Doubts and directions in Translation Studies. The Netherlands: John Benjamins.

Harvey, S. \& Higgins, I. 1986. Thinking Translation. London and New York. Routledge.

Kourouma, A. 1970. Les Soleils des Indépendances. Paris: Editions du Seuil.

Adrian, A. 1981. The Suns of Independence. London, Heinemann.

Larson, L. 1984. Meaning-Based Translation: A Guide to CrossLanguage Equivalence. Lanham, University Press of America.

Le Petit Robert 1978.

Nord, C. 1997. Translating as a purposeful Activity: Functionalist Approaches Explained. Manchester, St. Jerome.

Newmark, P. A Textbook of Translation, New York, Prentice Hall, 1988.

Nwoye, O. 1986. The Social Basis of Assumed Names in Igbo in Nigerian Journal of Humanities, no.8.

Oyono, F. 1966. Une Vie de Boy. Editions Julliard 1960.

John, R. 1966. The Houseboy. Great Britain, Heinemann.

Ozidi, B.2009. Translating African Names in Fiction in Ikala revisita de lenguaje y cultura, 14, 27-52.

Tymoczko, M. 1999. Translation in a Post-Colonial Context. Manchester, Saint Jerome Publishing Company.

\footnotetext{
Babatunde Samuel Moruwawon

University of Ado Ekiti,

Faculty of Arts, Department of French,

P.M.B.5363, Ado Ekiti, Ekiti State, Nigeria, West Africa

Phone Number: +234(0)8038224652

Email: tmoruwawon@yahoo.com
}

Received May 2010; Reviewed Jun. 2010; Revised version received Jun. 2010. 